\title{
PUSAT INFORMASI PENYAMPAIAN DAN PENGADUAN CIVITAS AKADEMIKA BERBASIS SMS GATEWAY PADA UNIVERSITAS BANDAR LAMPUNG (UBL) DENGAN KONSEP SERVICE ORIENTED ARCHITECTURE (SOA)
}

\author{
Yuthsi Aprilinda \\ Program Studi Teknik Informatika \\ Fakultas Ilmu Komputer \\ Universitas Bandar Lampung
}

Jln. Z.A. Pagar Alam No.26 Labuhan Ratu Bandar Lampung 35142

Telp. (0721) 701463, (0721) 701979 Fax. (0721) 701467 Web.

\begin{abstract}
Abstrak
SMS saat ini diimplementasikan oleh institusi sebagai remote monitoring, m-banking, e-commerce, sistem aktifasi, autorefil pulsa elektronik, sistem penyampaian informasi, dan lain sebagainya. implementasi SMS oleh perusahaan sebagai media penyampaian informasi dan media alternatif untuk menyampaikan informasi kantor kepada karyawannya yang pada umumnya menggunakan surat atau pengumuman melalui biro. Implementasi ini terkendala oleh terbatasnya waktu pada jam kerja kantor, informasi dapat sampai tepat waktu atau terlambat sesuai pro aktif para karyawan dan staf yang menyampaikannya. Permasalahan tersebut seharusnya dapat diatasi dan informasi kantor sampai tepat pada waktunya, jika lembaga memiliki sarana alternatif untuk menyampaikannya kepada karyawan dengan cara yang mudah.

Metode pengembangan perangkat lunak yang digunakan pada penelitian ini adalah model Waterfall, dan pengumpulan data dilakukan dengan metode observasi dan studi pustaka. Implementasi dari model Waterfall ini dijelaskan menggunakan diagram alir dokumen (DAD), konteks diagram, data flow diagram (DFD), struktur tabel database, relasi antar tabel, rancangan input output, dan flowchart program. Perancangan dan pembuatan sistem peyampaian informasi ini menggunakan Bahasa Pemrograman Borland Delphi dan database Paradox. Hasil penelitian ini adalah SMS Gateway yang berfungsi sebagai sistem pengaduan dan penyampaian informasi kepada civitas akademik Universitas Bandar Lampung, SMS gateway ini merupakan media alternatif lampus dalam menyampaikan informasi manajemen kepada civitas akademik.
\end{abstract}

Kata kunci: Sistem pengaduan dan penyampaian informasi civitas akademik

\section{PENDAHULUAN}

Short Message Service (SMS) saat ini banyak digunakan oleh masyarakat sebagai media komunikasi dan informasi. Perkembangan ini terlihat pada tingkat pertumbuhan yang sangat tinggi penggunaannya oleh masyarakat dalam waktu yang cukup singkat untuk berbagai keperluan. Dan hampir seluruh lapisan masyarakat memiliki handphone, sedangkan fasilitas SMS merupakan sarana yang banyak dimanfaatkan. Fenomena ini disebabkan biaya SMS yang murah, cepat, dan langsung pada tujuan. Keunggulan SMS lainnya adalah seseorang dapat melakukan komunikasi secara nonverbal kepada orang lain, dan hampir semua handphone memiliki fasilitas SMS dengan harga handphone yang terjangkau. Pilihan masyarakat untuk memiliki handphone, didukung oleh operator seluler (provider) yang semakin banyak dengan layanan tarif SMS yang murah, bahkan gratis untuk sesama operator. Selain itu juga, saat ini SMS diimplementasikan oleh institusi sebagai polling, m-banking, e-commerce, sistem aktifasi, autorefil pulsa elektronik, sistem penyampaian informasi, dan lain sebagainya. Media informasi ini akan menjadi sangat bermanfaat dalam memenuhi kebutuhan informasi jika diterapkan 
pada sistem yang banyak dimanfaatkan secara periodik, seperti penyampaian informasi dan pengaduan bagi civitas akademik. Berkaitan dengan implementasi SMS oleh civitas akademik sebagai media penyampaian informasi, pada umumnya manajemen kampus menyampaikan informasi kantor kepada civitas akademik menggunakan surat atau pengumuman melalui bagian personalia. Implementasi ini terkendala oleh terbatasnya waktu pada jam kerja kantor, informasi dapat sampai tepat waktu atau terlambat sesuai pro aktif para mahasiswa, dosen, dan karyawan yang menyampaikannya. Permasalahan tersebut seharusnya dapat diatasi dan kampus sampai tepat pada waktunya, jika manajemen kampus memiliki sarana alternatif untuk menyampaikannya kepada civitas akademik dengan cara yang mudah.

\subsection{Identifikasi Masalah}

Berdasarkan latar belakang masalah, pokok permasalahan pada penelitian ini sebagai berikut.

a. Penyampaian informasi manajemen kampus kepada civitas akademik menggunakan surat atau pengumuman melalui bagian personalia. Implementasi ini terkendala oleh terbatasnya waktu pada jam kerja kantor yang dapat menyebabkan keterlambatan sampainya informasi tersebut.

b. Penyerapan aspirasi civitas akademik melalui konsultasi atau pengaduan hanya diterima dan sering tidak ada tanggapan yang dapat ditindak lanjuti sehingga informasi pengaduan tersebut hanya formalitas saja sedangkan tidak ada jawaban dari manajemen kampus.

\subsection{Rumusan Masalah}

Berdasarkan identifikasi masalah di atas, peneliti merumuskan dalam penelitian ini adalah bagaimana membuat pusat informasi

\section{LANDASAN TEORI}

\subsubsection{Definisi Sistem}

Pengertian sistem menurut Supranto (2005), sistem adalah suatu set elemen-elemen atau komponen-komponen yang tergabung bersama berdasarkan suatu bentuk hubungan tertentu.komponen-komponen itu satu sama lain saling kait mengait dan membentuk suatu kesatuan yang utuh. Sistem merupakan suatu penyampaian dan pengaduan civitas akademik UBL berbasis SMS Gateway.

\subsection{Batasan Masalah}

Berdasarkan rumusan masalah di atas, batasan masalah pada penelitian ini sebagai berikut.

a. Penyampaian informasi melalui SMS kepada civitas akademik UBL terbatas kepada seluruh dosen, mahasiswa, karyawan, atau civitas akademik tertentu berdasarkan jenis informasinya.

b. Pengaduan melalui SMS dikelompokkan berdasarkan jenis pengaduannya dan manajemen kampus dapat membalas SMS keluhan tersebut.

\subsection{Tujuan Penelitian}

Penelitian ini bertujuan untuk:

a. Mengimplementasikan pusat informasi penyampaian dan pengaduan civitas akademik UBL melalui fasilitas SMS.

b. Menghasilkan pusat informasi penyampaian dan pengaduan civitas akademik UBL.

\subsection{Manfaat Penelitian}

Manfaat penelitian ini sebagai berikut.

a. Menghasilkan pusat informasi penyampaian dan pengaduan civitas akademik UBL.

b. Meningkatkan pelayanan informasi kepada mahasiswa UBL dan memudahkan manajamen kampus dalam menyampaikan informasi kepada civitas akademik.

\subsection{Manfaat Penelitian}

Manfaat penelitian ini sebagai berikut.

a. Menghasilkan pusat informasi penyampaian dan pengaduan civitas akademik UBL.

b. Meningkatkan pelayanan informasi kepada mahasiswa UBL dan memudahkan manajamen kampus dalam menyampaikan informasi kepada civitas akademik. susunan yang teratur dari kegiatan-kegiatan yang saling bergantung dan prosedur-prosedur yang saling berhubungan yang melaksanakan dan mempermudah kegiatan-kegiatan utama organisasi. Unsur-unsur sistem adalah mempunyai tujuan tertentu, suatu sistem terdiri dari banyak bagian, tiap-tiap bagian tersebut mempunyai kaitan dan hubungan satu dengan yang lainnya, bentuk dan penempatan dari masing-masing bagian sedemikian rupa, sehingga terlihat adanya harmonisasi. 


\subsection{Short Message Service (SMS)}

SMS atau layanan pesan singkat awalnya berfungsi untuk memberikan layanan pengiriman pesan teks singkat antarperangkat mobile phone (telepon genggam/ telepon bergerak), (Zakaria, 2006). SMS sebetulnya hanya layanan tambahan terhadap dua layanan utama (layanan voice dan switched data) dalam sistem jaringan Global System for Mobile Communications (GSM). Namun, karena keberhasilan SMS yang tidak terduga, dengan ledakan pelanggan yang mempergunakannya, menjadikan SMS sebagai bagian integral dari layanan sistem standar komunikasi lainnya, seperti code division multiple access (CDMA), universal mobile telecommunications system (UMTS), bahkan jaringan telepon rumah (fixed phone) juga mulai mengadopsi teknologi ini.

\subsubsection{Sistem Kerja SMS}

Dibalik tampilan menu messages pada ponsel sebenarnya adalah AT Command yang bertugas mengirim/ menerima data ke atau dari SMS-center. AT Command mirip perintah pada dos, untuk mengetes AT Command dapat menggunakan Windows HyperTerminal yang biasanya terdapat pada Windows installer. Dengan fasiliras tersebut, kita dapat membuka koneksi melalui port dengan SMS gateway, (Rozidi, 2004) AT Command untuk SMS biasanya diikuti oleh data I/O yg diwakili oleh unit-unit Protocol Data Unit (PDU). Data yang mengalir ke atau dari SMS-Center harus berbentuk PDU. DU berisi bilangan-bilangan heksadesimal yang mencerminkan bahasa I/O. PDU terdiri dari beberapa header, misalnya untuk mengirim SMS ada 8 header yang didalamnya terdapat lagi subheader-subheader sebagai berikut:

1. No SMS-Center

2. Type SMS (misalnya send atau recieve)

3. No Referensi SMS

4. No ponsel penerima

5. Bentuk SMS (sebagai sms atau fax)

6. Skema encoding data I/O

7. Jangka waktu (expired)

8. Isi SMS

Kedelapan header (berikut subheadernya) tersebut kita gabungkan menjadi sebuah PDU yang lengkap. Untuk memudahkan membaca bahasa PDU kita bisa menggunakan software untuk meng-encode dan men-decode PDU dari dan menjadi text biasa. Salah satunya adalah PDUSpy. Untuk meng atomatisasikan proses diatas kita bisa membuat aplikasinya dengan Visual Basic misalnya yang kemudian bisa dikembangkan lagi untuk aplikasi web.

\subsubsection{Arsitektur dan Elemen Jaringan SMS}

SMS merupakan sebuah layanan yang banyak diaplikasikan pada system komunikasi tanpa kabel, memungkinkan dilakukannya pengiriman pesan dalam bentuk alphanumeric antara terminal pelanggan atau antara terminal pelanggan dengan sistem eksternal seperti email, paging, voice mail, dan lain-lain. (Rozidi, 2004). Layanan SMS dibangun dari berbagai entitas yang saling terkait dan mempunyai fungsi dan tugas masing-masing. Secara umum arsitektur sistem SMS, khususnya untuk sistem yang diintegrasikan dengan jaringan wireless seperti Gambar 2.2.

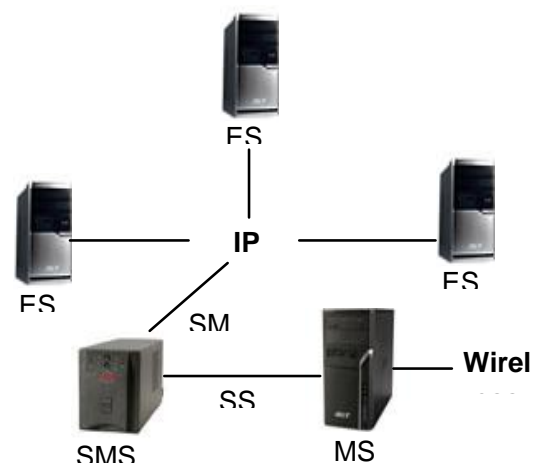

Gambar 2.2 Arsitektur Dasar Jaringan SMS

\subsubsection{Short Message Peer To Peer Protocol (SMPP)}

SMPP merupakan sebuah protokol standar industri yang digunakan dalam pertukaran short message antara eksternal short message entity (ESME), routing entity (RE), dan message center (MC). (Rozidi, 2004). MC merupakan terminologi generik untuk menyebutkan beberapa entitas seperti short message service center (SMSC), global system for mobile communication (GSM) unstructured supplementary services data (USSD) server, atau cell broadcast center (CBC). ESME merupakan entitas yang berada di luar jaringan komunikasi wirelss, berfungsi sebagai terminal penyedia layanan berbasis SMS seperti WAP Proxy Server, Email Gateway, atau Voice Mail Server. RE merupakan nama generik yang diberikan untuk menyebut beberapa entitas dalam 
sistem yang berfungsi melakukan routing SMS baik antar-message center maupun antara message center dengan ESME. Protokol SMPP dapat berjalan pada lapisan aplikasi, seperti halnya protokol-protokol lain dalam konteks komunikasi data dalam jaringan komputer seperti HTTP, FTP, Rlogin, WAP, dan lainnya. Satuan paket data yang dipertukarkan pada lapisan aplikasi dalam protokol SMPP disebut protocol data unit (PDU).

\section{METODOLOGI PENELITIAN}

Metodologi penelitian merupakan cara dan tahapan dalam perancangan serta pembuatan sistem yang akan diusulkan, implementasi metodologi penelitian tersebut menggunakan model Waterfall dengan tahapan sebagai berikut:

\subsection{System Engineering}

Rekayasa dan pemodelan sistem, dilakukan dengan mengumpulkan data melalui metode sebagai berikut.

\section{a. Observasi}

Melakukan pengamatan langsung di Universitas Bandar Lampung, dengan mengumpulkan data sistem penyampaian dan pengaduan civitas informasi civitas akademik kepada Biro Administrasi Akademik, Biro Administrasi Umum, Biro Pembinaan dan Pengembangan SDM, Biro Administrasi Keuangan, Biro Kemahasiswaan dan Hubungan Alumni, dan Biro Pemeliharaan dan Pengembangan Fasilitas Gedung.

\section{b.Studi Pustaka}

Mempelajari bahan-bahan pustaka dan literatur yang berkaitan dengan penelitian ini.

\section{c.Wawancara}

Wawancara adalah metode pengumpulan data dengan mengajukan pertayaan baik secara lisan maupun tulis untuk mendapatkan data tentang pengaduan dan penyampaian informasi civitas akademik UBL.

\subsection{Software Requirements Analysis}

Analisis kebutuhan perangkat lunak sistem penyampaian dan pengaduan civitas akademik UBL melalui fasilitas SMS. Kebutuhan tersebut meliputi kotak saran, laporan, surat penyampaian informasi, dan data civitas akademik. Tahapan selanjutnya adalah memilih software yang akan digunakan, yaitu Borland Delphi dan MySQL database.

\subsubsection{Peralatan Sistem yang diusulkan}

\section{Perangkat Keras (Hardware) Sistem}

Perangkat keras yang diusulkan mempunyai spesifikasi minimal:
a. Processor Intel P3 733
b. VGA $16 \mathrm{MB}$
c. RAM $128 \mathrm{MB}$
d. Harddisk $20 \mathrm{~GB}$
e. SVGA monitor 15 ,
f. CDROM 24x
g. Handphone Nokia 5110, 3210, 3310, 3315, 8210, 8250, dan Siemens C25, C35 dengan Simcard GSM dan Kabel serial FBUS
h. Keyboard dan mouse standar i. Printer standar.

Untuk lebih mengoptimalkan proses SMS Gateway, dapat digunakan spesifikasi hardware yang lebih tinggi.

\section{Perangkat Lunak (Software) Sistem}

Perangkat lunak yang diusulkan sebagai berikut.

1. Sistem operasi Microsoft Windows XP

2. Borland Delphi

3. MySQL Database

\section{HASIL DAN PEMBAHASAN}

\subsection{Perancangan (Design)}

Gambaran umum sistem pengaduan dan penyampaian informasi civitas akademik melalui SMS gateway dijelaskan melalui tahapan rancangan meliputi sistem yang diusulkan, database, relasi antar tabel, input output, dan flowchart program.

\subsubsection{Arsitektur Sistem}

Berdasarkan analisis dan kelemahan sistem yang berjalan, arsitektur sistem registrasi dan 
penyampaian informasi civitas akademik yang diusulkan dijelaskan pada gambar berikut.

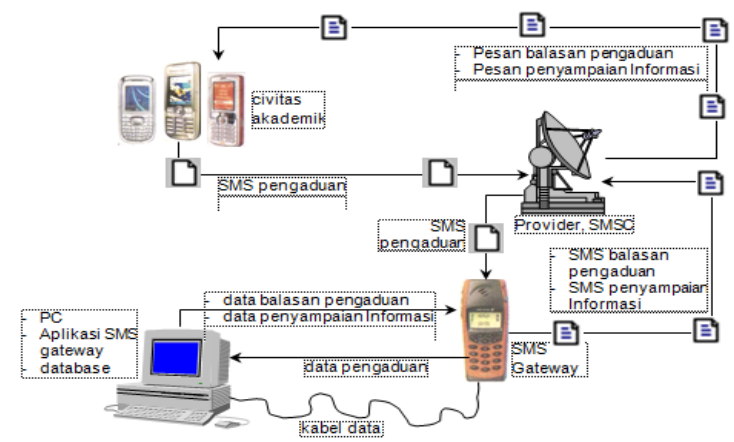

Gambar 4.1 Arsitektur Pengaduan dan Penyampaian Informasi

\subsubsection{Sistem yang diusulkan}

Sistem yang diusulkan dijelaskan menggunakan Konteks diagram dan data flow diagram (DFD).

\section{a. Konteks Diagram}

Konteks diagram yang diusulkan dijelaskan pada gambar berikut.

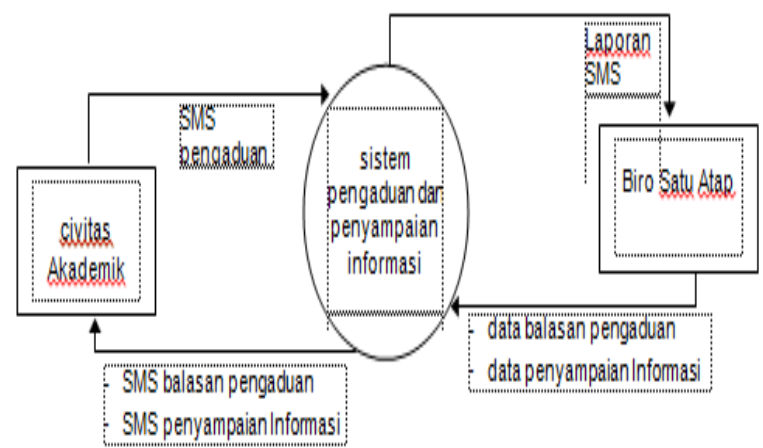

Gambar 4.2 Konteks Diagram

\section{b. Data Flow Diagram (DFD)}

DFD yang diusulkan dijelaskan pada Gambar 4.3.

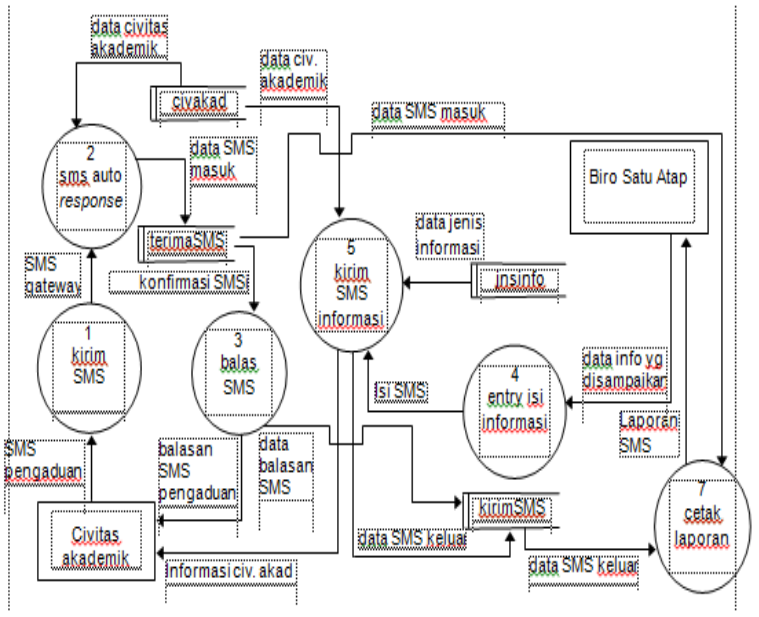

Flow Diagram (DFD)

\subsubsection{Rancangan Masukan (Input)}

Rancangan input sistem pengaduan dan penyampaian informasi civitas akademik berbasis SMS Gateway dijelaskan sebagai berikut.

\section{a. Rancangan input data jenis informasi}

Rancangan input data jenis informasi ditampilkan pada Gambar 4.5.

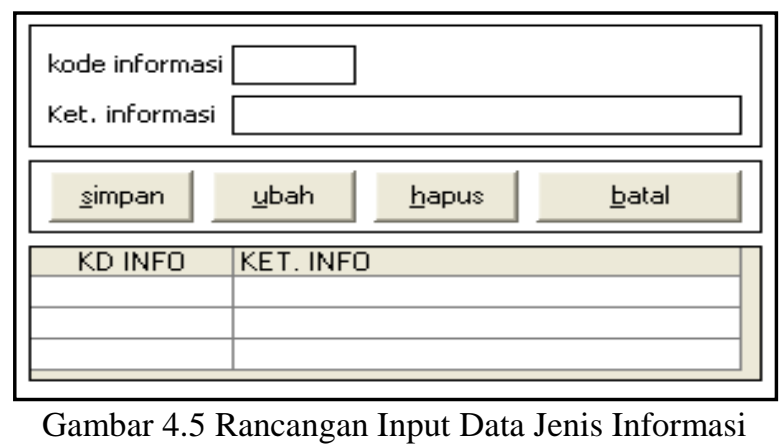

\section{b. Rancangan input data civitas akademik}

Rancangan input civitas akademik informasi dijelaskan pada Gambar berikut.

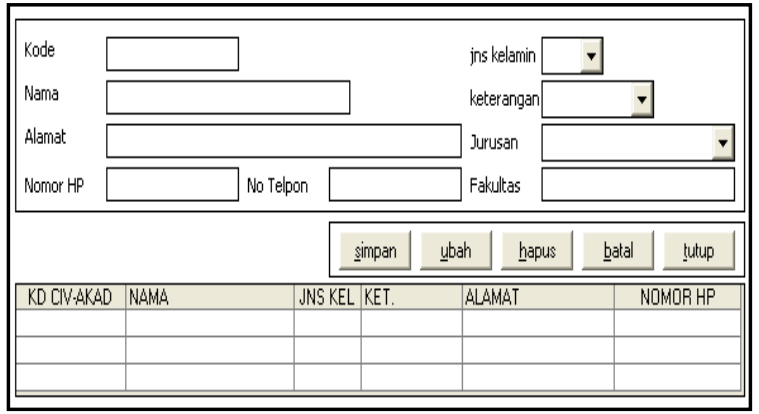


Gambar 4.6 Rancangan Input Data Civitas Akademik

\section{c.Rancangan input pengiriman informasi}

Rancangan input pengiriman informasi dijelaskan seperti pada Gambar 3.8.

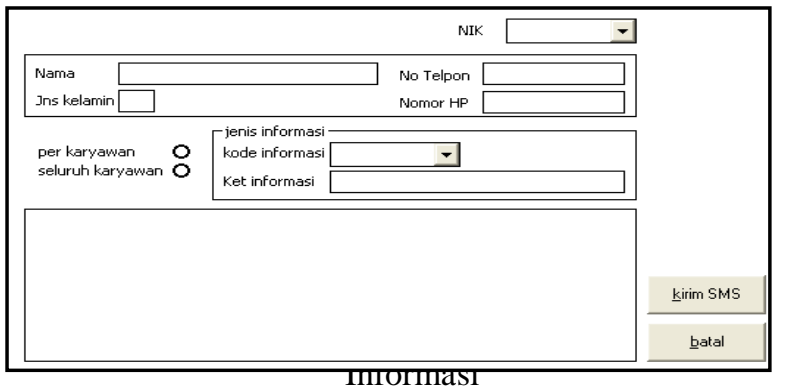

\subsubsection{Rancangan Keluaran (Output)}

Rancangan output sistem pengaduan dan penyampaian informasi civitas akademik berbasis SMS Gateway dijelaskan sebagai berikut.

1. Rancangan output data civitas akademik

Rancangan output data civitas akademik dijelaskan pada Gambar 4.8.

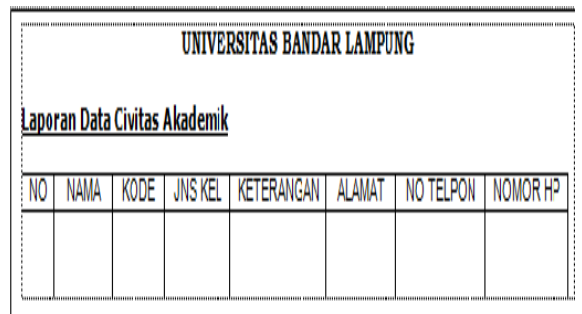

Rancangan output data penerimaan SMS di jelaskan pada Gambar 4.9.

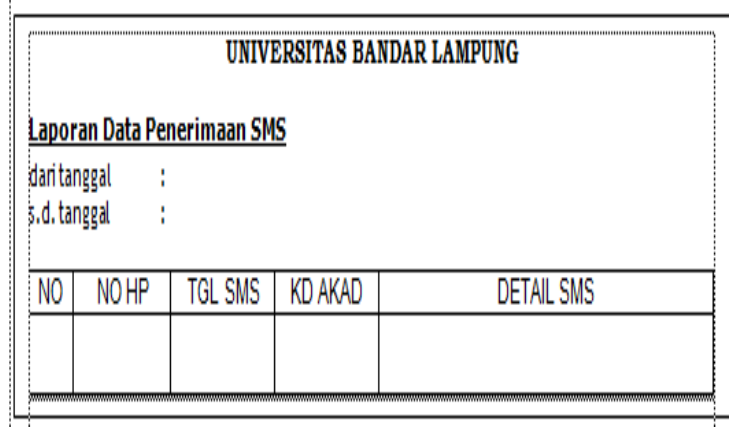

Gambar 4.9 Rancangan Output Data Penerimaan SMS

3. Rancangan output data pengiriman SMS
Rancangan output data pengiriman SMS dijelaskan pada Gambar 4.10.

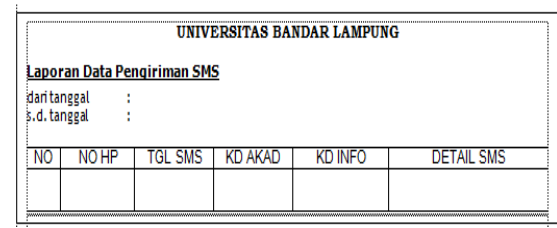

Gambar 4.10 Rancangan Output Data Pengiriman SMS

\subsubsection{Flowchart Program}

Logika program (flowchart) sistem pengaduan dan penyampaian informasi civitas akademik dijelaskan pada Gambar 4.11.

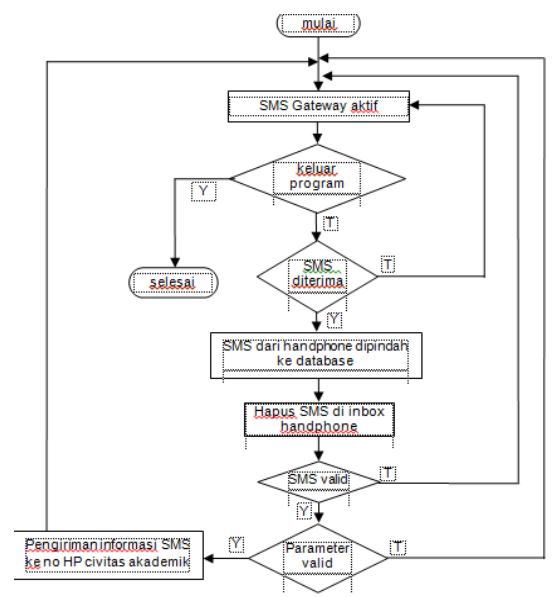

Gambar 4.11 Rancangan Flowchart Program

\subsection{Mekanisme SMS}

Cara pengaduan dan penyampaian informasi civitas akademik melalui SMS gateway dijelaskan pada Tabel 4.5 .

Tabel 4.5 SMS yang dikirim atau diterima Civitas akademik

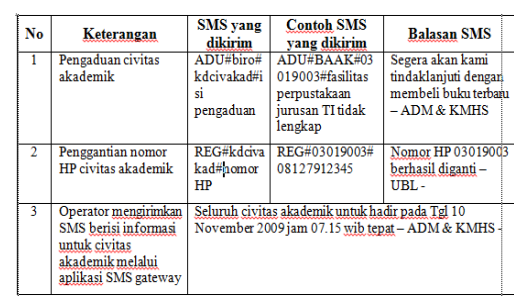

\subsection{Tampilan Program}

Sistem registrasi dan penyampaian informasi karyawan melalui SMS ini, dijelaskan melalui 
hasil tampilan-tampilan program SMS Gateway sebagai berikut.

\subsubsection{Menu Utama}

Saat pertama kali program dijalankan, ditampilkan menu utama, pada menu utama tersebut terdapat fasilitas untuk menjalankan fasilitas untuk mengaktifkan SMS Gateway, menonaktifkan SMS Gateway, data informasi, data biro, data civitas akademik, kirim SMS, dan laporan data SMS. Untuk menampilkan program yang diinginkan, user mengklik gambar icon atau pada tulisannya, adapun tampilan menu utama tersebut dijelaskan pada Gambar 4.12.

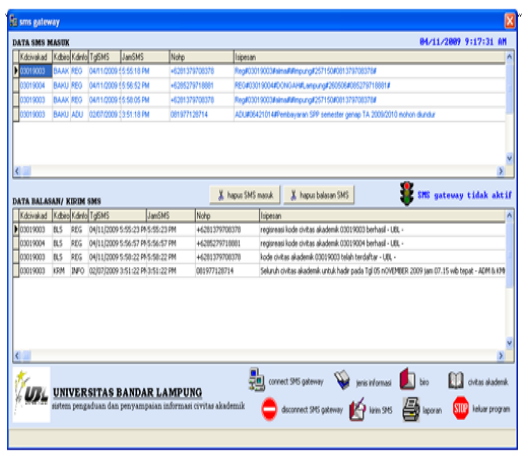

Gambar 4.12 Tampilan Menu Utama

Berdasarkan Gambar 4.12 di atas, untuk mengaktifkan SMS Gateway, user mengklik icon komputer atau tulisan connect SMS gateway, jika kabel dan HP telah terhubung ke PC pada menu utama akan ditampilkan tulisan SMS gateway aktif seperti pada Gambar 4.13 dan pada menu utama akan ditampilkan tulisan SMS gateway tidak aktif seperti pada Gambar 4.14 jika kabel dan HP belum terhubung ke PC.

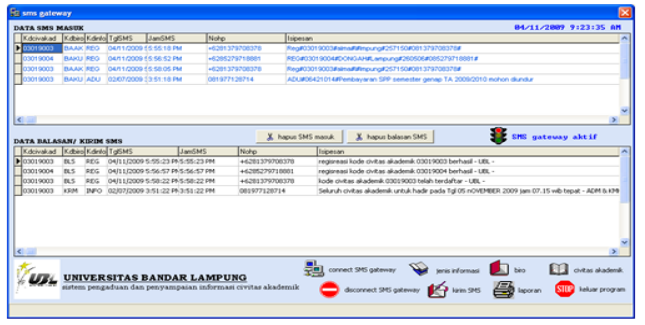

Gambar 4.13 Tampilan SMS Gateway Terhubung

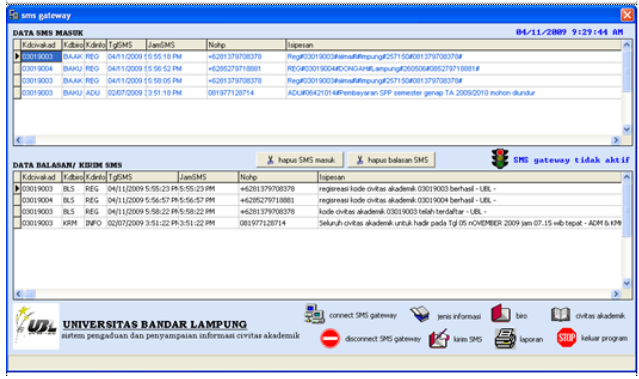

Gambar 4.14 Tampilan SMS Gateway Tidak Terhubung

Pada menu utama tersebut, user dapat menonaktifkan koneksi SMS Gateway dengan mengklik icon atau $\rightarrow$ san disconnect SMS gateway, dan setiap SMS yang diterima atau keluar tersimpan di tabel DATA SMS MASUK atau DATA BALASAN/ KIRIM SMS pada menu utama.

\subsubsection{Master Informasi}

Pada menu utama, user mengklik icon buku atau tulisan jenis informasi dan akan ditampilkan program master informasi. User memasukkan kode dan keterangan informasi kemudian mengklik tombol simpan jika akan menambah data baru, dan jika akan memperbaiki data tersebut user memasukkan kode yang telah ada dan ditampilkan keterangan informasi secara otomatis, untuk mengubah data user langsung mengganti data yang telah ditampilkan tersebut dengan mengklik tombol ubah dan untuk menghapus data user mengklik tombol hapus. Adapun tampilan master informasi tersebut dijelaskan pada Gambar 4.15.

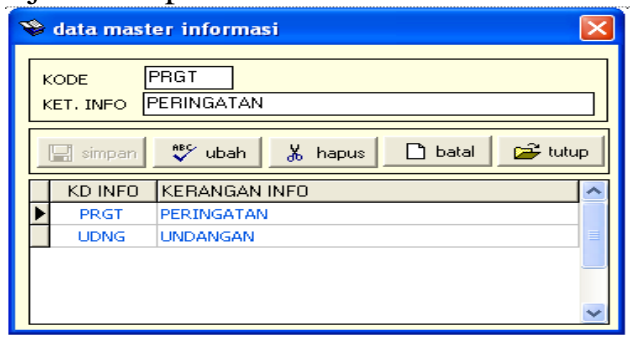

Gambar 4.15 Tampilan Program Master Data Informasi

\subsubsection{Master Civitas Akademik}

Pada menu utama, user mengklik icon buku atau tulisan civitas akademik dan akan 
ditampilkan program master civitas akademik. User memasukkan kode, nama, jenis kelamin, alamat, nomor telpon, nomor HP civitas akademik, fakultas, dan jurusan kemudian mengklik tombol simpan jika akan menambah data baru, dan jika akan memperbaiki data tersebut user memasukkan kode civitas akademik yang telah ada dan ditampilkan nama, jenis kelamin, alamat, nomor telpon, dan nomor HP civitas akademik secara otomatis, untuk mengubah data user langsung mengganti data yang telah ditampilkan tersebut dengan mengklik tombol ubah dan untuk menghapus data user mengklik tombol hapus. Adapun tampilan master data karyawan tersebut dijelaskan pada Gambar 4.16 .

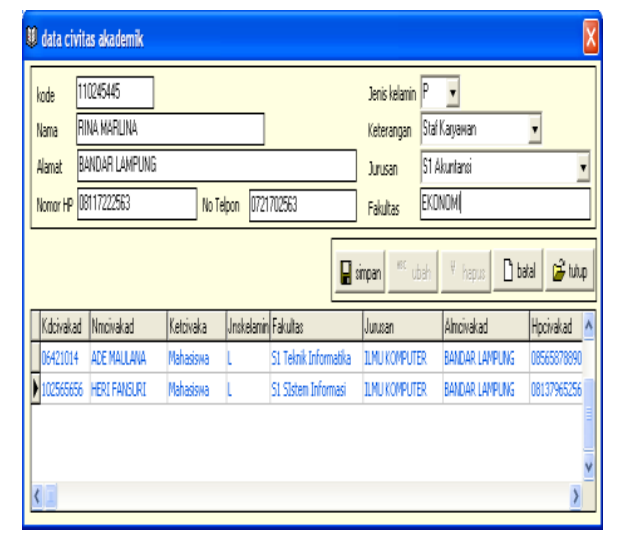

Gambar 4.16 Tampilan Master Data Civitas Akademik

\subsubsection{Master Data Biro}

Pada menu utama, user mengklik icon buku atau tulisan biro dan akan ditampilkan program master data biro. User memasukkan kode dan keterangan biro kemudian mengklik tombol simpan jika akan menambah data baru, dan jika akan memperbaiki data tersebut user memasukkan kode yang telah ada dan ditampilkan keterangan biro secara otomatis, untuk mengubah data user langsung mengganti data yang telah ditampilkan tersebut dengan mengklik tombol ubah dan untuk menghapus data user mengklik tombol hapus. Adapun tampilan master biro tersebut dijelaskan pada Gambar 4.17.

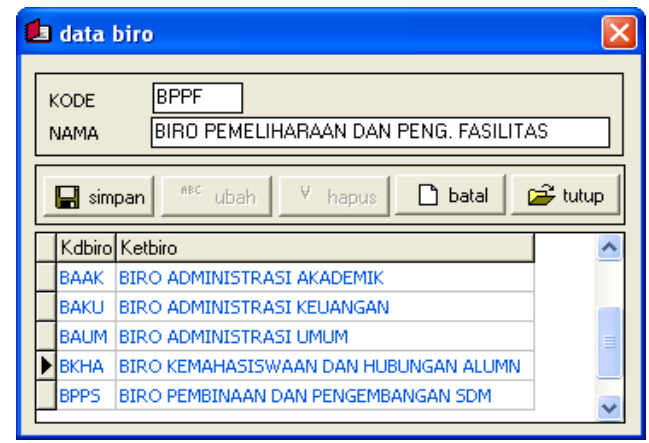

Gambar 4.17 Tampilan Program Master Data Biro

\subsubsection{Pengiriman SMS}

Untuk mengirimkan SMS informasi kepada civitas akademik, user mengklik icon buku atau tulisan kirim SMS pada menu utama dan akan ditampilkan program pengiriman SMS, selanjutnya user memilih kode civitas akademik dan jenis informasi kemudian memasukkan informasi yang akan dikirim ke karyawan melalui SMS, jika mengirimkan SMS hanya untuk civitas akademik tertentu user memilih pilihan per civitas akademik dan pilihan semua civitas akademik jika SMS akan dikirim kepada seluruh civitas akademik kemudian user mengklik tombol kirim SMS. Adapun tampilan program untuk mengirimkan SMS tersebut dijelaskan pada gambar berikut ini.

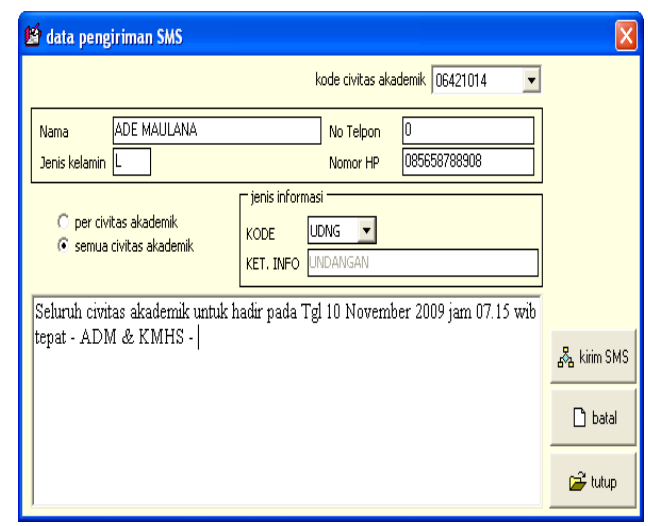

Gambar 4.18 Tampilan Program Kirim SMS

\subsubsection{Program Laporan}

Pada menu utama, user mengklik icon pronter atau tulisan laporan dan akan ditampilkan program laporan seperti Gambar 4.19.

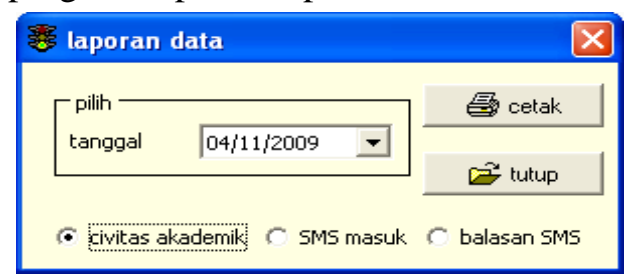

Gambar 4.19 Tampilan Program Laporan

Berdasarkan Gambar 4.19 di atas, user dapat menampilkan laporan dengan memilih tanggal dan jenis laporan. Hasil tampilan laporan 
data civitas akademik seperti pada Gambar 4.20, laporan data SMS masuk seperti pada Gambar 4.21, dan laporan data kirim SMS seperti pada Gambar 4.21.

Gambar 4.20 Tampilan Laporan Data Civitas Akademik

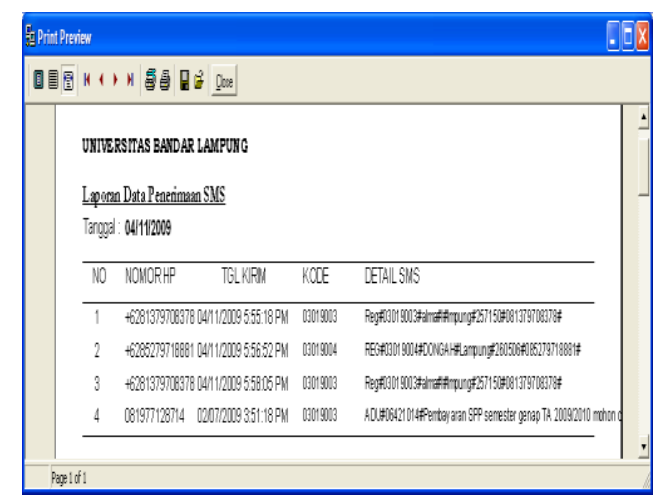

Gambar 4.21 Tampilan Laporan Data SMS Masuk

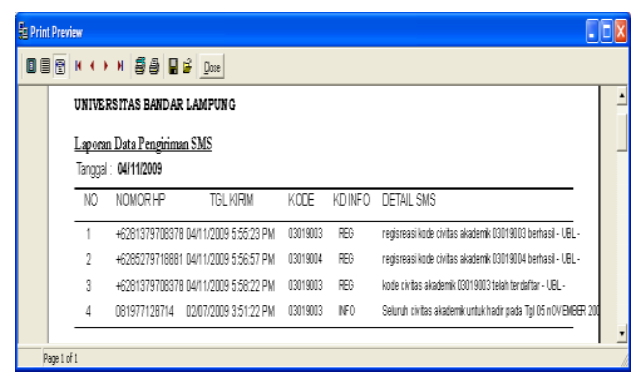

Gambar 4.21 Tampilan Laporan Data Kirim SMS

\subsection{Pembahasan}

Sistem pengaduan dan penyampaian informasi kepada civitas akademik UBL berbasis SMS Gateway ini bersifat autoresponse atau program akan merespon SMS yang masuk secara otomatis, dengan memeriksa isi dari SMS c. informasi kampus kepada civitas akademik.

\section{Daftar Pustaka}

tersebut. Dan jika isi SMS sesuai parameter, SMS Gateway akan membalas ke nomor HP pengirim sesuai SMS yang diterima. Pada pengujian ini, civitas akademik mengirimkan biodatanya dengan mengirimkan SMS Request sebagai berikut.

\section{REG\#KODE CIVITAS AKADEMIK\# NO HP \\ ADU\#KODE CIVITAS AKADEMIK\#BIRO\#ISI PENGADUAN}

\section{INF\#KODE CIVITAS AKADEMIK\#ISI INFORMASI}

Setelah SMS dikirimkan, maka program akan memeriksa adanya SMS baru yang masuk ke handphone. Selanjutnya pengecekan SMS tersebut terdiri atas 3 tahap yaitu :

1. Memeriksa apakah SMS tersebut valid atau tidak sebagai SMS Request

2. Memeriksa apakah kode regsitrasi sesuai kode SMS (REG/ADU/INF)

3. Memeriksa apakah permintaan kode civitas akademik terdaftar pada database

\section{SIMPULAN DAN SARAN}

Berdasarkan analisis hasil dan pembahasan, dapat disimpulkan sebagai berikut:

a. Sistem pengaduan dan penyampaian informasi civitas akademik resmi UBL, dilakukan dengan surat melalui masingmasing Biro atau menempelkan informasi tersebut pada papan informasi kampus. Dan belum adanya media alternatif untuk menyampaikan informasi kepada karyawan secara langsung, dan tidak terkendala oleh terbatasnya waktu pada jam kerja kantor yang dapat menyebabkan keterlambatan sampainya informasi kampus tersebut.

b. SMS Gateway pada penelitian ini berfungsi sebagai sistem pengaduan dan penyampaian informasi civitas akademik melalui SMS pada UBL, dan merupakan media alternatif perusahaan dalam menyampaikan

[1] Cahyanto. 2004. Aplikasi SMS dengan Visual Basic 6.0 dan Mobile FBUS. PT. Elex Media Komputindo. Jakarta. 
[2] Debdikbud. 1998. Kamus Besar Bahasa Indonesia. Balai Pustaka, Jakarta

[3] Dennis, Alan. Barbara H Wixom. 2007. System Analysis Design 2nd Edition. Jhon Wiley and Son. Inc United States of America.

[4] Fathansyah. 2004. Basis Data. Informatika. Bandung

[5] Jogiyanto. 2001. Analisa Desain dan Sistem Informasi. Andi. Yogyakarta.

[6] Martina, Inge. 2001. Database menggunakan Delphi. PT. Elex Media Komputindo. Jakarta.

[7] Rozidi, Romzi Imron. 2004. Membuat Sendiri SMS Gateway (ESME) Berbasis Protokol. Andi. Yogyakarta.

[8] Sukamto. 2001. Analisis Sistem Komputer. Andi. Yogyakarta.

[9] Supranto. 2005. Teknik Pengambilan Keputusan. Rineka Cipta. Jakarta.

[10] Sutanta, Edhy. 2003. Sistem Informasi Manajemen. Graha Ilmu. Yogyakarta.

[11] Zakaria, Widiadhi. 2006. Aplikasi SMS untuk Berbagai Keperluan. Informatika. Bandung. 